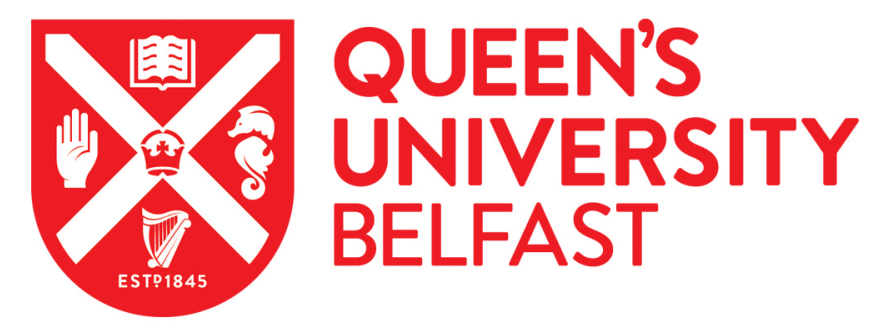

\title{
The EU-Russia relationship and the EU Energy Union: from Dependence and Vulnerability towards Competition and a Free Flow
}

Martyniszyn, M. (2016). The EU-Russia relationship and the EU Energy Union: from Dependence and Vulnerability towards Competition and a Free Flow. In R. J. Heffron, \& G. F. M. Little (Eds.), Delivering Energy Law and Policy in the EU and the US. (pp. 145-150). Edinburgh University Press.

https://edinburghuniversitypress.com/book-delivering-energy-law-and-policy-in-the-eu-and-the-us.html

Published in:

Delivering Energy Law and Policy in the EU and the US.

Document Version:

Peer reviewed version

Queen's University Belfast - Research Portal:

Link to publication record in Queen's University Belfast Research Portal

Publisher rights

Copyright Raphael J. Heffron, 2015

\section{General rights}

Copyright for the publications made accessible via the Queen's University Belfast Research Portal is retained by the author(s) and / or other copyright owners and it is a condition of accessing these publications that users recognise and abide by the legal requirements associated with these rights.

Take down policy

The Research Portal is Queen's institutional repository that provides access to Queen's research output. Every effort has been made to ensure that content in the Research Portal does not infringe any person's rights, or applicable UK laws. If you discover content in the Research Portal that you believe breaches copyright or violates any law, please contact openaccess@qub.ac.uk. 
The final version of this contribution is forthcoming in:

DELIVERING ENERGY LAW AND POLICY IN THE EU AND THE US: A READER

(Raphael J. Heffron \& Gavin Little, eds., Edinburgh University Press), Forthcoming

\title{
The EU-Russia relationship and the EU Energy Union: from Dependence and Vulnerability towards Competition and a Free Flow
}

\author{
Marek Martyniszyn ${ }^{1}$, Lecturer in Law, Queen's University Belfast, UK.
}

The EU-Russia relationship is characterised by co-dependence in various areas, including in the case of gas trade. On the EU side, the Member States to a varying degree are dependent on Russian gas imports. Some (Bulgaria, Estonia, Finland, Latvia, and Lithuania) used to fully rely on Russian gas. Overall, the Russian gas amounts to about one third of EU's gas imports and a quarter of its consumption. ${ }^{2}$ The EU's dependence on Russian gas is reinforced by the nature of gas trade and the poor infrastructure. Majority of gas is still transported through pipelines. In Central and Eastern Europe most of them run from East to West, with few interconnections and limited storage capacity. While globally the trade in liquefied natural gas (LNG) is on the rise, until recently in the EU's Central and Eastern Member States (including Finland) there was no single LNG terminal capable to receive LNG. $^{3}$ Therefore, Gazpromthe state-controlled firm enjoying a monopoly on Russian gas exports—had a considerable leverage over some Member States, which may be unable in the short or even medium term to switch to other suppliers or energy sources.

On the other side, Russia exports its gas almost exclusively through pipelines. ${ }^{4}$ Due to high cost and time involved in pipeline construction, Russia is dependent on its current foreign gas customers. As half of Russian gas exports flow to Europe, ${ }^{5}$ in the short and medium term Russia

\footnotetext{
${ }^{1}$ Dr Marek Martyniszyn, Lecturer in Law, Queen’s University Belfast. Email: m.martyniszyn@qub.ac.uk. Dr Martyniszyn specialises in the international and transnational aspects of competition law and policy, including the limits of extraterritorial jurisdiction and the issue of state involvement in anticompetitive practices. In broader terms, his research interests lie in international economic law. Before joining QUB's School of Law, Dr Martyniszyn was a Senior Research Fellow in the Institute for Consumer Antitrust Studies at the Loyola University Chicago School of Law. He holds a PhD degree from University College Dublin (Ireland) and an LLM from the European Institute of the Saarland University (Germany).

2 ENI, O\&G: World Oil and Gas Review (2012), available at <http://www.eni.com/world-oil-gas-review2012/static/pdf/wogr-2012.pdf> accessed 1 March 2015.

3 See Gas Infrastracture Europe, 'Gas LNG Europe' (June 2014), available at <http://www.gie.eu/download/maps/2014/GLE_LNG_JUNE2014.pdf> accessed 1 March 2015.

${ }^{4}$ Russia opened its first and only LNG export terminal in 2009. Gazprom, First Russian LNG Plant Launched in Sakhalin (18 February 2009), available at <http://www.gazprom.com/press/news/2009/february/article64569/> accessed 1 March 2015.

${ }^{5}$ Margarita Assenova, 'Russian Energy Review in 2012: Consolidating State Control in an Uncertain Market', Eurasia Daily Monitor, 18 January 2013, available at <http://www.jamestown.org/single/?no_cache=1\&tx_ttnews[tt_news]=40333\&tx_ttnews[backPid]=620\#.UhtkE j_pww4> accessed 1 March 2015.
} 
may not be able to sell the 'European' gas elsewhere. Moreover, significant part of Russian federal budget revenues come from hydrocarbons exports. The scale of reliance on such revenues suggests that 'a reduction in natural gas sales would be politically catastrophic'. ${ }^{6}$ Furthermore, Russia operates a multi-tier pricing for gas. Domestic prices are regulated and set below cost. ${ }^{7}$ Gazprom, which is responsible for about $70 \%$ of Russia's total gas production, is able to cross-subsidize. It uses the export profits to cover the domestically generated loses, and still generates profits to fill state coffers. A significant increase in domestic gas price could destabilize industrial sector and may have a significant impact on the population. In effect, Russia relies on its gas sales to Europe. The relationship is one of co-dependence.

Simultaneously, while Russia needs its European gas sales, it does not seem dependent on sales to a particular country (but for Germany-Russia's most important customer). So long as Russia is able to negotiate deals with individual states - not the EU as a whole, it enjoys considerable bargaining power. This makes it possible to use gas exports also for other purposes. In fact, prices for Russian gas differ greatly across the EU without a clear economic reasoning justifying the differences. ${ }^{8}$ Moreover, it is well-established that Russia used its energy lever for strategic, foreign policy aims multiple times in the past. $^{9}$

In this context, in November 2013 the European Commission opened a formal proceedings against Gazprom. ${ }^{10}$ The Commission was concerned that Gazprom may be abusing its dominant position on gas supply markets in certain Member States, in breach of EU competition law. In particular, three types of possible anticompetitive practices are under scrutiny: 1) use of 'no resale' clauses in supply contracts, which may be hindering free flow of gas in the EU; 2) prevention of diversification of gas supplies; and 3) imposition of unfair pricing by linking oil and gas prices in long-term contacts. ${ }^{11}$ In a sudden reaction, only a week after the opening of the proceedings the Russian President issued a blocking Order, negatively affecting foreign enforcement efforts in case of all Russian strategic enterprises, Including Gazprom. ${ }^{12}$ Most likely due to the developments in Ukraine, the Commission's proceedings were put on hold.

\footnotetext{
${ }^{6}$ Aviezer Tucker, 'The New Power Map: World Politics After the Boom in Unconventional Energy', Foreign Affairs, 19 December 2012, available at <http://www.foreignaffairs.com/print/135945> accessed 1 March 2015.

7 Gazprom, Setting fair gas prices in Russia to boost domestic economy (22 April 2014), available at <http://www.gazprom.com/press/news/2014/april/article189315/> accessed 1 March 2015.

${ }^{8}$ See the graph of alleged Russian gas prices provided by Izvestia <http://izvestia.ru/news/544100> accessed 1 March 2015.

${ }^{9}$ See, for example, a study by Larsson from the Swedish Defence Research Agency Robert L. Larsson, Russia's Energy Policy: Security Dimensions and Russia's Reliability as an Energy Supplier, FOI-R--1934--SE (2006), available at <http://storage.globalcitizen.net/data/topic/knowledge/uploads/20110731213514705.pdf> accessed 1 March 2015.

${ }^{10}$ European Commission, IP/12/937, Antitrust: Commission Opens Proceedings Against Gazprom (4 September 2012), available at <http://europa.eu/rapid/press-release_IP-12-937_en.htm> accessed 1 March 2015.

${ }^{11}$ Alan Riley, 'Commission v. Gazprom: The Antitrust Clash of the Decade?' (CEPS Policy Brief No. 285, 2012), 8-10, available at $\langle$ http://www.ceps.eu/ceps/dld/7433/pdf > accessed 1 March 2015. For more on the broader geopolitical context of this case see also Marek Martyniszyn, 'The EU's case against Gazprom is about far more than business', 24 April 2015, available at <https://theconversation.com/the-eus-case-against-gazprom-is-aboutfar-more-than-business-40773> accessed 11 May 2015.

${ }^{12}$ Marek Martyniszyn, 'Legislation Blocking Antitrust Investigations and the September 2012 Russian Executive Order', 37(1) World Competition 103 (2014).
} 
Against this backdrop, the on-going Ukrainian crisis further exposed the EU's import dependence and vulnerability, with Russia threatening to cut off gas supplies over the winter. Unexpectedly, this situation created an opportunity by providing a much-needed stimulus to unite the EU on the energy issue.

In April 2014 Donald Tusk - now the President of the European Council, then the Polish Prime Minister - called for creation of an Energy Union. ${ }^{13}$ He proposed founding it on six principles. First, the EU was to develop a mechanism for jointly negotiating energy contracts with Russia. Tusk suggested having a single European body charged with buying gas, in order to 'confront Russia's monopolistic position'. He proposed its implementation in stages. First, bilateral agreements were to be stripped of any market-distorting clauses. Second, a template gas purchase contract was to be developed. Third, the European Commission was to take part in all new gas purchase negotiations. Other five principles suggested by Tusk related to mechanisms guaranteeing energy solidarity in case of cut-offs; expanding of EU's energy infrastructure (both interconnections and storage capacity); making full use of the existing fossil fuel resources; and reaching out to new gas suppliers.

Tusk's proposal built on similar plea by Jerzy Buzek, then the President of the European Parliament, and Jacques Delors, one of the 'fathers of Europe', who called for creation of a European Energy Community, already in 2010. ${ }^{14}$ They also recommended the EU having 'a single interface' in relations with both the energy producer and transit counties. They stressed the need for the EU to be able to pool its supply capacities and to 'engage in coordinated energy purchasing' 15

The idea of the Energy Union has been embraced by the new European Commission, led by Jean-Claude Juncker, who became the new Commission's President in November 2014. Juncker has identified it as one of his top priorities. ${ }^{16}$ In February 2014 the European Commission published its vision — a framework strategy towards the Energy Union. ${ }^{17}$ The Commission has already invested a considerable political capital in this project. Maroš Šefčovič, the Commission's Vice-President responsible for the Energy Union, descripted this

\footnotetext{
13 Donal Tusk, A united Europe can end Russia's energy stranglehold, <http://www.ft.com/cms/s/0/91508464c661-11e3-ba0e-00144feabdc0.html> accessed 1 March 2015.

14 Jerzy Buzek and Jacques Delors, 'Towards a new EEC', 5 May 2010, available at <http://www.europarl.europa.eu/meetdocs/2009_2014/documents/envi/dv/815/815663/815663en.pdf> accessed 1 March 2015.

${ }^{15}$ Buzek was actively promoting the idea of joint or coordinated gas purchases among the chiefs of the EU's gas companies. See Jerzy Buzek, 'Buzek makes case for gas purchases coordination in EU with energy CEOs', 20 April 2011, available at <http://www.sitepres.europarl.europa.eu/president/de-en/press/press_release/2011/2011April/press_release-2011-April-15.html> accessed 1 March 2015.

${ }^{16}$ Jean-Claude Juncker, 'A New Start for Europe: My Agenda for Jobs, Growth, Fairness and Democratic Change. Political Guidelines for the next European Commission', 15 July 2014, available at <http://ec.europa.eu/priorities/docs/pg_en.pdf> accessed 1 March 2015.

${ }^{17}$ European Commission, Energy Union Package: A Framework Strategy for a Resilient Energy Union with a Forward-Looking Climate Change Policy, $\operatorname{COM}(2015) \quad 80$ final (25 February 2015), available at <http://ec.europa.eu/priorities/energy-union/docs/energyunion_en.pdf> accessed 1 March 2015.
} 
initiative as 'the most ambitious European energy project since the Coal and Steel Community'. ${ }^{18}$

The Commission framed the presented strategy around five dimensions and 15 action points. The first of the identified dimensions is 'Energy security, solidarity and trust'. It encompasses diversification of supplies, in terms of sources, suppliers and routes. The strategy talks also about assessing options for voluntary demand aggregation mechanism for collective purchasing of gas 'during a crisis and where Member States are dependent on a single supplier [emphasis added]'. ${ }^{19}$ The fact that only voluntary schemes are envisaged means that the Commission is not currently considering proposing creation of some sort of a central gas purchasing agency, or state-mandated arrangements. The Commission also provides that any voluntary arrangements would need to be compliant with the EU competition rules and WTO law. This clarification is important as such mechanisms may be also described as buying cartels, which may be raising competition concerns, if capable of exerting sufficient market power. ${ }^{20}$

The European Commission proposes also an ex ante compliance checks with EU law of any proposed intergovernmental agreements between Member States and third countries, in relation to energy supplies, gas in particular. In the Commission's view its participation in such negotiations and development of standard contract clauses can help 'avoid undue pressure and ensure respect of European rules'. ${ }^{21}$

The framework strategy is comprehensive. For example, it outlines actions which need to be taken in order to fully integrate European energy market, and it underlines the importance of measures aimed at improving energy efficiency and its contribution to the moderation of demand.

In order to deliver on its promise, the Commission outlined also 15 inter-linked action points. First provides that 'full implementation and strict enforcement of existing energy and related legislation is the first priority to establish the Energy Union.' As it is further clarified, the Commission will take action to endure that the Member Statues filly implement energy legislation and it will be strictly enforcing EU competition law in this area. ${ }^{22}$ This is important declaration and it echoes a recent signalling by the EU's Competition Commissioner of the readiness to 'move forward' with the pending antitrust investigation of the Gazprom

\footnotetext{
${ }^{18}$ European Commission, IP/15/4497, Energy Union: secure, sustainable, competitive, affordable energy for every European (25 February 2015), available at <http://europa.eu/rapid/press-release_IP-15-4497_en.htm> accessed 1 March 2015.

${ }^{19}$ European Commission (n 17) at 6.

${ }^{20}$ Noteworthy, the EU's interest in collaborative purchasing is not unique. Various Asian countries, which absorb a large part of global LNG exports, are considering such schemes in order to secure better contract terms and pricing. First joint purchases have already taken place. For example, in 2014 Korea Gas Corporation (KOGAS), reportedly the world's largest LNG buyer, teamed up for a joint gas purchase with Japan Oil, Gas and Metals National Corporation (JOGMEC). Jane Chung, 'Japan firm buy gas together; more joint deals to come', Reuters, 24 March 2014, available at <http://reut.rs/1gsxphc> accessed 1 March 2015.

${ }^{21}$ European Commission (n 17) at 8.

${ }^{22}$ Ibid, at 19.
} 
practices. ${ }^{23}$ Indeed, in April 2015 the Commission has issued a Statement of Objection to Gazprom, formally outlining the charges. ${ }^{24}$

Whether the EU's Energy Union materialises depends on the political commitment of the Member States and the EU institutions. The circumstances are favourable. In the recent years the dependence pendulum has swung in the EU's favour. The growing exploitation of shale gas in the USA and the growth in the LNG trading contributed to lower prices (also of coal), facilitating necessary adjustments. Lithuania opened its first LNG terminal. Another terminal is close to completion in Poland. First, much-needed cross-border interconnections are operational (Poland-Czech Republic, Slovakia-Hungary) and more are being worked on. ${ }^{25}$ Moreover, the EU started using reverse gas flow. It is now possible to, for example, pass Russian gas originally sent to Germany via the North Stream, to Poland or Italy, if needs be. Finally, the Member States have recently demonstrated respect of EU law in the context of the planned South Stream pipeline. While Russia concluded bilateral agreements with a number of Member States in that regard, the European Commission found them in breach of EU law and the project was ultimately abandoned.

The outlined framework strategy constitutes is a very ambitious, multi-dimensional project, economically and politically. The EU's single market is not yet complete. The delivery on the Energy Union promise would be an important step towards its completion. The European integration started from the ashes of the World War II. The founders of what is now the EU pragmatically began with economic integration, which was to have and indeed has had spillover effects beyond economics. A more interconnected and competitive single energy market would bring the EU's citizens more prosperity and it would also, by addressing unbalanced import dependence, contribute towards cementing peace, which-as the ongoing Ukrainian crisis blatantly shows us-should not be taken for granted.

\footnotetext{
23 'Vestager: Commission ready to move forward with Gazprom probe', EurActiv, 19 February 2015, available at <http://www.euractiv.com/sections/energy/vestager-commission-ready-move-forward-gazprom-probe-312250> accessed 1 March 2015.

${ }^{24}$ European Commission, IP/15/4828, Commission sends Statement of Objections to Gazprom for alleged abuse of dominance on Central and Eastern European gas supply markets (22 April 2015), available at http://europa.eu/rapid/press-release_IP-15-4828_en.pdf.

25 See the infographic in 'Conscious uncoupling', The Economist, 5 April 2014, available at <http://www.economist.com/news/briefing/21600111-reducing-europes-dependence-russian-gas-possiblebut-itwill-take-time-money-and-sustained> accessed 1 March 2015.
} 